\title{
Effect of tillage on bare soil energy balance and thermal regime: an experimental study
}

\author{
Guy Richard ${ }^{\mathrm{a} *}$, Pierre Cellier ${ }^{\mathrm{b}}$ \\ a Inra, Unité d'agronomie de Laon-Péronne, 02007 Laon Cedex, France \\ ${ }^{b}$ Inra, Unité de recherches en bioclimatologie, 78850 Thiverval-Grignon, France
}

(Received 22 January 1998; accepted 26 May 1998)

\begin{abstract}
The effects of tillage on the energy balance and temperature of bare soil were studied using three plots that had different soil structures due to different times of seedbed preparation and soil compaction. The experiment was performed on a loamy soil (Gleyic luvisol) in northern France during the establishment of sugar beet in spring 1992. Temperature, water content, heat capacity and thermal conductivity of the ploughed layer, surface albedo and roughness, net radiation, soil heat flux, sensible heat flux and evaporation were all measured over a spring-tilled soil, an autumn-tilled soil and a compacted soil. Differences in soil heat fluxes were related to soil evaporation and thermal conductivity. Differences in soil temperatures were related to heat capacity. In spite of a considerable evaporation, the compacted soil had the highest soil heat flux because of its high thermal conductivity. Nevertheless, the spring-tilled soil was the warmest because of its low heat capacity, and sugar beet germinated more rapidly with spring soil tillage. (@ Inra/Elsevier, Paris.)
\end{abstract}

\section{soil tillage / soil structure / temperature / energy balance / thermal properties}

Résumé - Effet du labour sur le bilan d'énergie et le régime thermique d'un sol nu : étude expérimentale. Une expérimentation a été conduite dans un sol limoneux (Gleyic luvisol) dans le Nord de la France pendant la phase d'implantation d'une culture de betterave sucrière au printemps 1992 pour étudier les effets du travail du sol sur le bilan d'énergie et sur le régime thermique du sol. La température, l'humidité, la capacité calorifique, la conductivité thermique au sein de la couche labourée, l'albédo et la rugosité de la surface, le rayonnement net, le flux de chaleur dans le sol et dans l'air et le flux de chaleur latente ont été mesurés dans un sol travaillé au printemps, dans un sol travaillé à l'automne ou dans un sol fortement compacté. Les différences de flux de chaleur dans le sol entre traitements étaient liées aux niveaux d'évaporation et à la conductivité thermique ; les différences de température étaient liées à la capacité calorifique. Le sol fortement compacté avait le flux de chaleur le plus élevé malgré un niveau d'évaporation important, à cause de sa forte conductivité thermique. Mais c'était le sol travaillé au printemps qui était le plus chaud à cause de sa faible capacité calorifique, entraînant une germination des betteraves sucrières plus rapide. (@ Inra/Elsevier, Paris.)

travail du sol / structure du sol / température / bilan d'énergie/ propriétés thermiques

Communicated by Jim Douglas (Penicuik, U.K.)

* Correspondence and reprints

E-mail: richard@laon.inra.fr 


\section{INTRODUCTION}

Soil temperature is an important variable in many processes. It influences plant growth and development (germination, emergence, root development and functioning), soil microbial activity (decomposition of organic matter, nitrogen transformations), physical factors (viscosity and surface tension of water) and physical processes (transport of water, gases and solutes).

Soil temperature depends mainly on the climate, but permanent or temporary soil characteristics can also cause temperature differences of several $\mathrm{K}$ between soils under the same climate [8, 24]. For example, soil texture influences the albedo of the soil surface and the thermal regime of the soil: chalky soils with a high albedo warm more slowly than loamy soils with a lower albedo [8]. Soil temperature can also be affected by agricultural practices which modify the soil surface (natural or artificial mulches, roughness, ridges), the soil compactness and the soil water regime. Numerous studies have dealt with the effect of soil tillage on soil temperature [29]. They generally compared the effects of conventional tillage (with annual deep tillage) and minimum tillage (without annual deep tillage), or different forms of conventional tillage. It is not easy to summarize their findings because soil thermal regime can be described by many variables such as thermal time calculated with different base temperatures, temperature and/or soil heat flux recorded once a day or every hour, mean or maximum and minimum temperatures during a day. The measurements can also be made at different depths, at different periods of the year and with or without a crop. Nevertheless, it is generally agreed that minimum tillage leaves the soil colder than conventional tillage (up to $4 \mathrm{~K}$ [14]). The depressive effect of minimum tillage on soil temperature is generally attributed to lower maximum temperatures [15] linked to the presence of crop residues at the soil surface which increase soil albedo. But minimum tillage can also reduce evaporation because of the crop residues and consequently increase soil heat flux and soil temperature [13]. The differences between various conventional tillage techniques (chisel/mouldboard/rotavator, deep/shallow ploughing, fall/spring ploughing) can reach $2 \mathrm{~K} \mathrm{[14]}$ and are generally smaller than those between conventional and minimum tillage. Contradictory results have also been reported. Autumn tillage can produced a lower or a higher maize seed bed temperature in spring than did spring tillage $[2,28]$. Soil temperatures can be higher after deep tillage with mouldboard ploughing than with chisel [23] or with no-tillage without surface residues [1]. In both cases, the warmest soil had a lower thermal conductivity and heat capacity, and a higher soil heat flux. On the contrary, a compacted ploughed layer can be warmer than an uncompacted ploughed layer and it had a higher thermal conductivity and a heat capacity, and finally higher soil heat flux [3].

Soil thermal regime depends on both the soil heat flux and its partitioning in depth. Soil heat flux is one of the four fluxes of the energy balance and consequently, its magnitude depends on those of the other fluxes: net radiation, latent heat flux, sensible heat flux towards the atmosphere. These four fluxes depend on the climatic conditions (solar and atmospheric radiation, air temperature, air humidity, wind speed), the soil state variables (surface temperature and water content), and the soil physical parameters. Soil parameters can directly modify the fluxes of the energy balance (albedo, emissivity, roughness, thermal conductivity), or they can modify the soil state variables (hydraulic conductivity, heat capacity). Contradictory results could be due to the effect of tillage on soil parameters other than the thermal properties, which are generally the only ones measured. Soil compactness also affects soil hydraulic properties [18], which can greatly modify soil heat flux [26]. A smooth soil has a higher albedo than a rough soil, and consequently less available energy at the soil surface [2], a smooth soil also has a lower aerodynamic roughness which can limit the loss of energy by sensible and latent heat fluxes, and consequently enhance the soil heat flux [25]. It is therefore necessary to describe most of the parameters and processes modified by soil tillage to obtain a better understanding of the relationships between soil tillage and soil temperature [3]. 
Soil temperature is very important for crop emergence and early growth, particularly for crops such as sugar beet which is sown at the beginning of spring in north-western Europe when the soil is cold [4]. Secondary tillage can greatly affect the structure of the ploughed layer at sugar beet sowing [27]. It could be managed to enhance soil warming in spring and to reduce the time for sugar beet emergence. The main variables in the secondary tillage are the date of tillage, which defines the length of time the tilled soil is exposed to frost and rainfall until sowing, and the water content of the soil at tillage, which governs soil compaction under tractor wheel tracks and soil loosening after tool operation. We have therefore examined the effects of various types of tillage on soil temperature in order to improve rules of decision making for secondary tillage. We measured most of the variables and parameters which could influence the soil heat flux and its partitioning in depth: energy balance components, albedo, roughness, soil water content, soil hydraulic and thermal characteristics. Three different soil structures in the ploughed layer, simulating a wide range of soil conditions at sugar beet sowing, were compared. They differed in the timing of secondary tillage after ploughing and before sowing and in their degree of compactness.

\section{MATERIALS AND METHODS}

\subsection{Experimental sites}

The field experiment was conducted during sugar beet establishment in the spring of 1992 near Laon $\left(49^{\circ} 34 \mathrm{~N}, 3^{\circ} 38 \mathrm{E}\right)$ in France. Three experimental treatments were studied:

S: mouldboard ploughing in autumn (November 1991) and secondary tillage with a combined cultivator in spring (days 97 and 101) just before sugar beet sowing (day 101);

A: mouldboard ploughing and secondary tillage with a reciprocating harrow in autumn (September 1991);
C: treatment A which was compacted in March 1992 in wet conditions with a heavy tractor whose tyres were inflated at $300 \mathrm{kPa}$.

For treatments $\mathrm{A}$ and $\mathrm{C}$, the sowing was carried out with no tillage in spring. With treatments $A$ and $S$, we wanted to vary the structural discontinuity between the seed bed and the sub-layers, which might affect soil water evaporation and soil heat flux. With treatments A and $\mathrm{C}$, we expected no difference in the structural continuity between the seed bed and the sub-layers and we wanted two levels of ploughed layer bulk density.

The experimental area was at the southern end of a farm field (about $10 \mathrm{ha}$ ) where the tillage operations described in treatment $S$ were used. The plot for treatment A was $100 \mathrm{~m} \times 100 \mathrm{~m}$ and the plot for treatment $\mathrm{C}$ was and $10 \mathrm{~m} \times 20 \mathrm{~m}$. The plots were large enough for micrometeorological methods to be used to assess the sensible heat flux over treatments A and S. The neighbouring crops were sugar beet on three sides and wheat on the eastern side, which ensured no large flux discontinuity at the field boundaries. The soil was classified as a silt loam (Gleyic luvisol, FAO classification). It contains $12 \%$ clay, $81 \%$ silt, $7 \%$ sand (percent mineral fraction) and $2 \%$ organic matter. Sugar beet was sown on day 101 and the sensors were installed between days 104 and 108. Measurements were continued until the sugar beet plants had two leaves (day 137), so that plant transpiration was always negligible compared to soil evaporation.

\subsection{Measurements, fluxes and assessment of soil properties}

Table I summarizes the measurements. Sensors were placed and soil samples were extracted between the sugar beet rows, as functions of the wheel tracks made during secondary tillage and sowing. The thermocouples used to measure surface temperature were held on the soil surface with a thin plastic stem and coated with mud at the time of installation, to give them optical properties similar to the surrounding soil [17]. These thermocouples were inserted into the soil inside $25 \times 5 \mathrm{~mm}$ stainless steel tubes [17].

The energy exchange between the soil and the atmosphere was investigated by analysing its energy balance:

$$
R_{n}=G+H+\lambda E
$$

where $R_{n}$ is net radiation, $G$ is the soil heat flux, $H$ is the sensible heat flux towards the atmosphere and $\lambda E$ is the latent heat flux. 
Table I. Measurements made over each plot (number of replication) and measuring devices used.

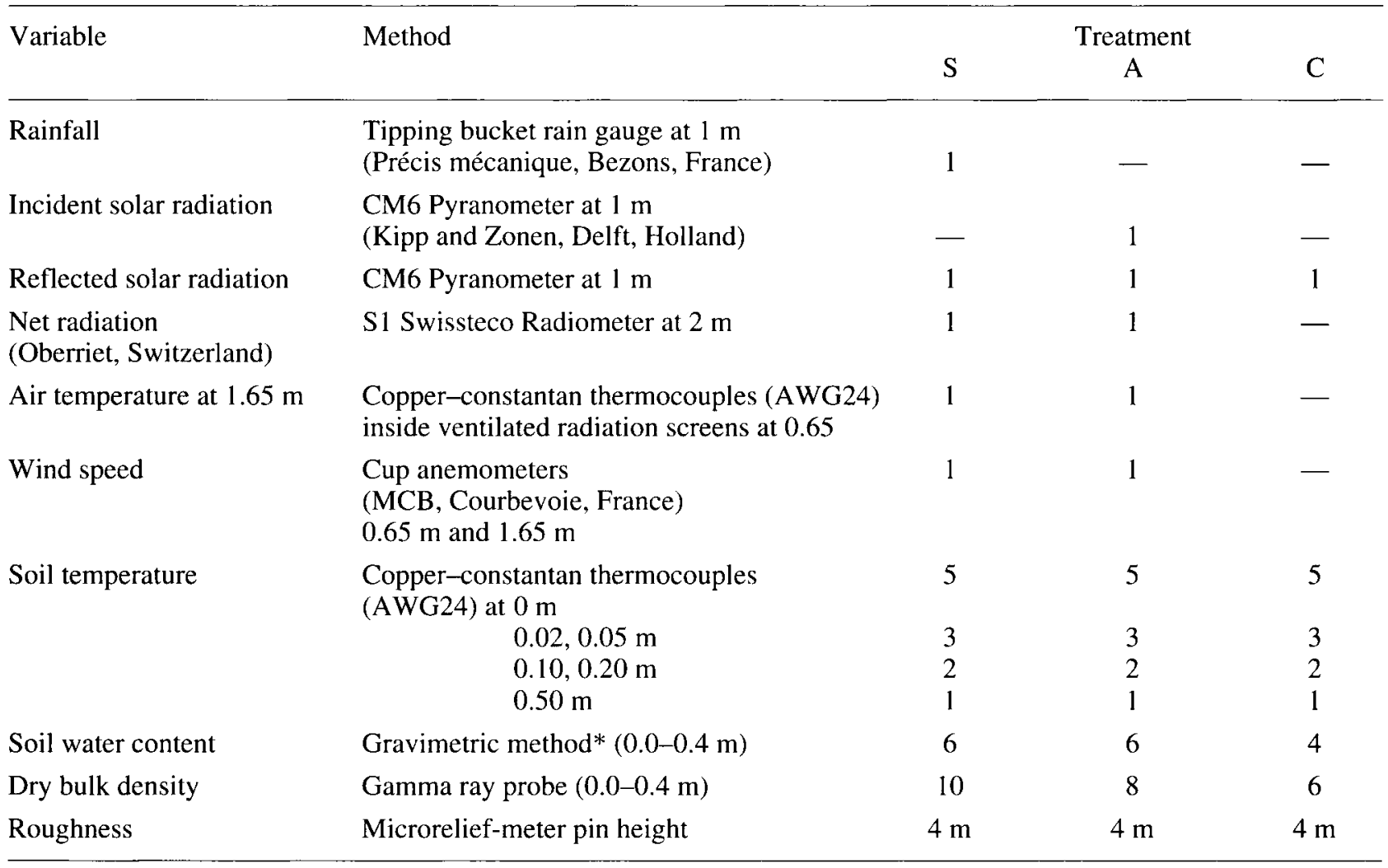

* Layers $(\mathrm{m}): 0-0.005,0.005-0.01,0.01-0.02,0.02-0.03,0.03-0.04,0.04-0.05,0.05-0.07,0.07-0.10,0.10-0.15,0.15-0.20$, $0.20-0.25,0.25-0.30,0.30-0.40$

Net radiation can be partitioned into four terms describing solar and thermal radiation:

$$
R_{n}=(1-a) R_{s}+\varepsilon^{\prime} R_{a}-\varepsilon \sigma T_{0}^{4}
$$

where $R_{s}$ and $R_{a}$ are the solar (short wave) and atmospheric (long wave) radiation, $a$ is the soil albedo, $\varepsilon^{\prime}$ and $\varepsilon$ are the soil emissivities for absorption and emission of long wave radiation, $\sigma$ is the Stefan-Boltzmann constant $\left(5.67 \times 10^{-8} \mathrm{~W} \mathrm{~m}^{-2} \mathrm{~K}^{-4}\right)$, and $T_{0}$ is the soil surface temperature. The parameters $\varepsilon^{\prime}$ and $\varepsilon$ are generally considered to be equal [5]. Net radiation was measured directly using a net radiometer.

The soil heat flux was estimated by the calorimetric method, using the formula:

$$
G=G_{d}+\int_{0}^{z d} C(z)(\partial T / \partial t)_{z} \mathrm{~d} z
$$

where $z$ is the depth and $T$ is the temperature. $G_{d}$ is the soil heat flux at a depth $z_{d}$ where it is much smaller than
$G$ and $C(z)$ is the volumetric heat capacity of the soil. Soil temperature was measured at six depths $(0.00,0.02$, $0.05,0.10,0.20$ and $0.50 \mathrm{~m}$ ) using thermocouples. The depth $z_{d}$ was taken as the arithmetic mean of the two lowest measurements (i.e. at $0.35 \mathrm{~m}$ ). $G_{d}$ was calculated from equation (4) assuming that the heat is transferred in the soil only by conduction:

$$
G=-k_{s}(\partial T / \partial z)_{z}
$$

where $k_{s}$ is the apparent thermal conductivity of the soil, using soil temperatures measured at 0.20 and $0.50 \mathrm{~m}$ and a thermal conductivity estimated as $1.5 \mathrm{~W} \mathrm{~m}^{-1} \mathrm{~K}^{-1}$ [8].

The volumetric heat capacity was calculated for two soil layers $(0.00-0.02 \mathrm{~m}$ and $0.05-0.10 \mathrm{~m})$ as a linear relationship between the soil bulk density and its water content at different depths by the method of de Vries [11]. The apparent thermal conductivity, $k_{s}$, was calculated for the same soil layers from the soil temperature 
gradient and the heat flux by inverting equation (4). Average values from night-time temperature profiles ( 0 a.m. -5 a.m.) were used for this, because the soil heat fluxes are more stable during the night than during the day.

The sensible heat flux to the atmosphere $H$ was estimated by a simplified aerodynamic method from the temperature and wind gradients between 0.5 and $1.5 \mathrm{~m}$ [22]. It included stability corrections and used a free convection expression when the Richardson number was below -0.30 . The latent heat flux $\lambda E$ was calculated as the residual term of the energy balance equation (equation (1)).

The sensible heat flux and the latent heat flux are convective fluxes that depend on turbulent transfers in the lower part of the atmosphere. The latent heat flux also depends on the availability of water at the soil surface. These two fluxes can therefore be expressed using the resistance analogy with the following formula [7]:

$$
\begin{gathered}
H=\rho c_{p} \frac{T_{0}-T_{a}}{r_{a h}} \\
\lambda E=\rho L \frac{\left[h \cdot q_{s a t}\left(T_{0}\right)-q_{a}\right]}{r_{a v}+r} \\
\text { with } h=\exp \left(\Psi_{0} \cdot g / R \cdot T_{0}\right)
\end{gathered}
$$

where $\rho$ is the air density $\left(\mathrm{kg} \mathrm{m}^{-3}\right), c_{p}$ is the specific heat capacity of dry air $\left(\mathrm{J} \mathrm{kg}^{-1}\right), L$ is the latent heat of vaporization $\left(\mathrm{J} \mathrm{kg}^{-1}\right), T_{0}$ is the soil surface temperature $(\mathrm{K}), T_{a}$ is the air temperature at a reference level $(\mathrm{K}), q_{\text {sat }}\left(T_{0}\right)$ is the saturated water vapour mixing ratio $\left(\mathrm{kg} \mathrm{kg}^{-1}\right.$ dry air) at temperature $T_{0}, q_{a}$ is the mixing ratio of the air at the reference height $\left(\mathrm{kg} \mathrm{kg}^{-1}\right.$ dry air $), r_{a h}$ is the aerodynamic resistance to heat transfer $\left(\mathrm{s} \mathrm{m}^{-1}\right), r_{a v}$ is the aerodynamic resistance to water vapour transfer $\left(\mathrm{s} \mathrm{m}^{-1}\right), r_{s}$ is the soil resistance to evaporation $\left(\mathrm{s} \mathrm{m}^{-1}\right), \psi_{0}$ is the water suction at the soil surface $(\mathrm{m}), g$ is the acceleration of force fall $\left(9.81 \mathrm{~m}^{2} \mathrm{~s}^{-1}\right)$, and $R$ is the ideal gas constant $\left(8.314 \mathrm{~J} \mathrm{~mol}^{-1} \mathrm{~K}^{-1}\right)$. The aerodynamic resistances to heat and water vapour transfer are assumed to be equal when the transfers of heat and mass are turbulent $\left(r_{a}=r_{a h}=r_{a v}\right.$ [7]). The aerodynamic resistance depends on wind speed, surface roughness and the vertical gradients of temperature and water vapour, the resistance to evaporation $r_{s}$ depends on the availability of water at the soil surface. The parameter $h$ is different from 1.0 only in dry conditions, for water suctions greater than $0.3 \mathrm{MPa}$, corresponding to a water content of $0.12 \mathrm{~g} \mathrm{~g}^{-1}$ in our soil.

Micrometeorological and soil temperature measurements were recorded every $5 \mathrm{~s}$ by a CR 10 datalogger and averaged over 30-min intervals. Soil water contents were measured every 2 or 3 days. Dry bulk density was measured only once, at the end of the experiment. All the measurements were made in a sub-plot of $20 \mathrm{~m} \times$ $20 \mathrm{~m}$ in the centre of the plot. The experimental plots were small enough to ensure that air temperature and wind speed at $1.5 \mathrm{~m}$ were similar for all treatments. The differences in the air temperature and in the wind speed between the two plots were used to estimate the error of measurement due to the probes and data-loggers. The differences in the air temperature were generally less than $0.2 \mathrm{~K}$, sometimes around $0.3 \mathrm{~K}$ and they varied in the same direction as the difference at the soil surface. Consequently, we considered temperature difference between two treatments at a given depth to be significant if they were greater than $0.3 \mathrm{~K}$. The difference in the daily wind speed was very low $\left( \pm 0.05 \mathrm{~m} \mathrm{~s}^{-1}\right)$.

\section{RESULTS}

\subsection{Meteorological conditions during the experimental period}

The meteorological conditions varied considerably, as shown in figure 1. Air temperature varied from 3 to $20^{\circ} \mathrm{C}$, while the difference between air temperature and dew point went from $2 \mathrm{~K}$ on a rainy day to $10 \mathrm{~K}$ on a dry one. Solar radiation was 5-30 $\mathrm{MJ} \mathrm{m}^{-2} \mathrm{day}^{-1}$. The wind varied from light $\left(1 \mathrm{~m} \mathrm{~s}^{-1}\right)$ to strong $\left(6 \mathrm{~m} \mathrm{~s}^{-1}\right)$. There were three rainy periods: days $105-108$ (cumulative rainfall $=$ $11 \mathrm{~mm}$ ), days $117-122$ (cumulative rainfall = $22 \mathrm{~mm}$ ) and days $130-132$ (cumulative rainfall = $16 \mathrm{~mm}$ ), and three dry periods with different reference evapotranspiration levels: days $109-116\left(\mathrm{E}_{0}=\right.$ $\left.2.4 \mathrm{~mm} \mathrm{day}^{-1}\right)$, days $123-129\left(\mathrm{E}_{0}=3.5 \mathrm{~mm} \mathrm{day}^{-1}\right)$ and days $133-137\left(\mathrm{E}_{0}=5.1 \mathrm{~mm}^{\mathrm{day}}{ }^{-1}\right)$.

\subsection{Ploughed layer structure}

Plot A was tilled in the autumn, and winter rainfall (240 mm from October to March) had compacted the seed bed and degraded the soil surface structure. A thick crust developed during the winter (10-20 mm thick), leaving no distinct aggre- 

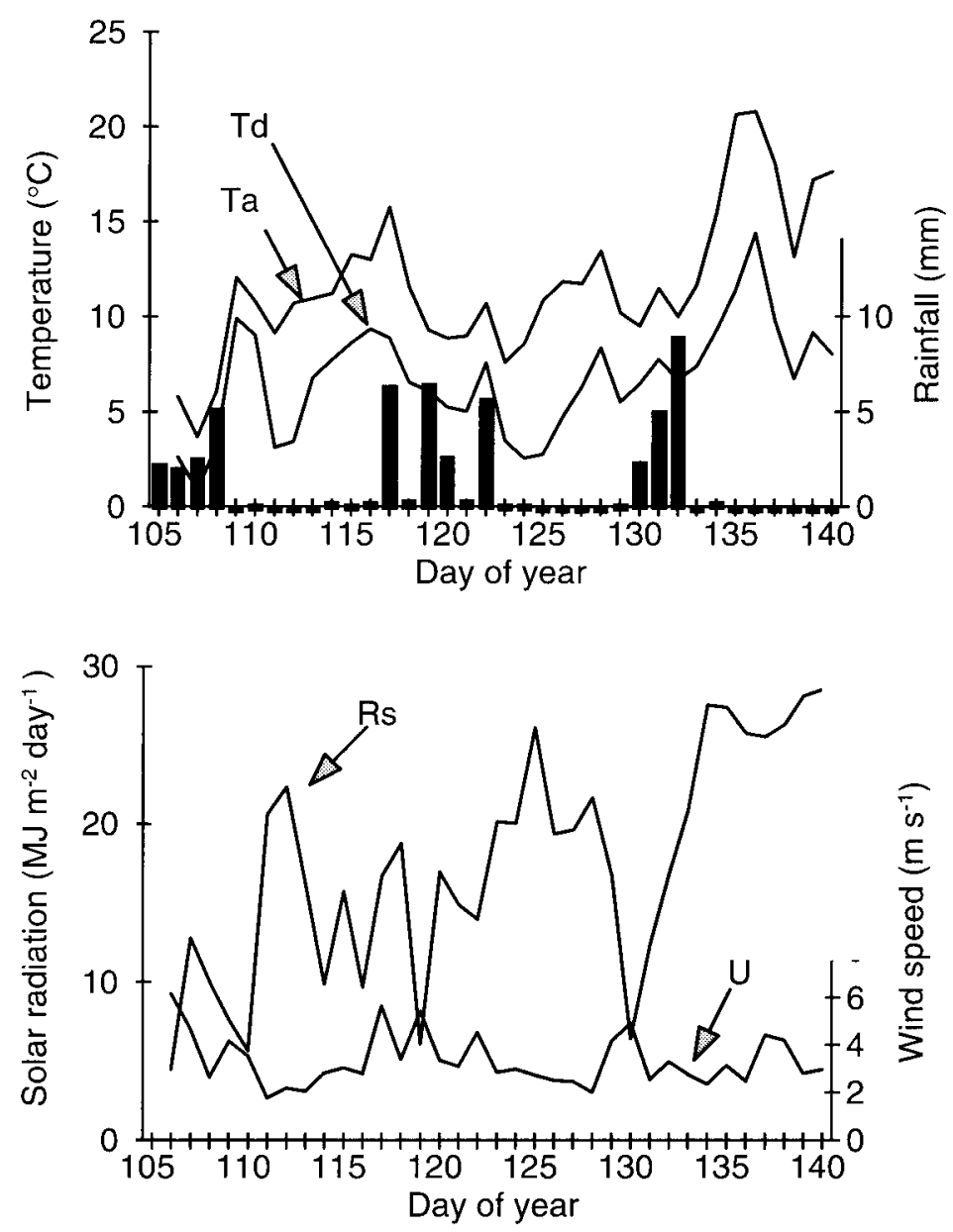

Figure 1. Daily averages for air temperature (Ta), dew point (Td), rainfall, solar radiation (Rs) and wind speed (U) during the experiment.

gates at the soil/atmosphere interface. The surface was particularly smooth, with a random roughness near zero (corresponding to the standard deviation of the heights). The dry bulk density of the seed bed $(0-0.08 \mathrm{~m}$ layer) was lower in plot $\mathrm{S}$ than in plot A (figure 2). The spring soil tillage on plot $S$ just before sugar beet sowing gave a loose and fragmentary seed bed with a great fraction of aggregates smaller than $20 \mathrm{~mm}\left(780 \mathrm{~g} \mathrm{~kg}^{-1}\right.$ dry soil). The surface random roughness was $2.2 \mathrm{~mm}$. The mean dry bulk densities in the tilled layer under the seed beds of plots $\mathrm{A}$ and $\mathrm{S}$ were similar. Plot $\mathrm{C}$ had a massive structure throughout the ploughed layer and it was the densest soil (figure 2) because of the severe compaction produced by the wheels of the tractor under wet conditions.

\subsection{Albedo and thermal properties}

Figure 3 shows the change with time in the albedo on the three plots. Albedo was lower during rainy periods, when the soil surface was wet, than during dry periods. It was generally $\mathrm{S}<\mathrm{A}<\mathrm{C}$, but it was $\mathrm{A}<\mathrm{S}<\mathrm{C}$ during the first dry period (days 112-117). The smooth soil surface and some white 


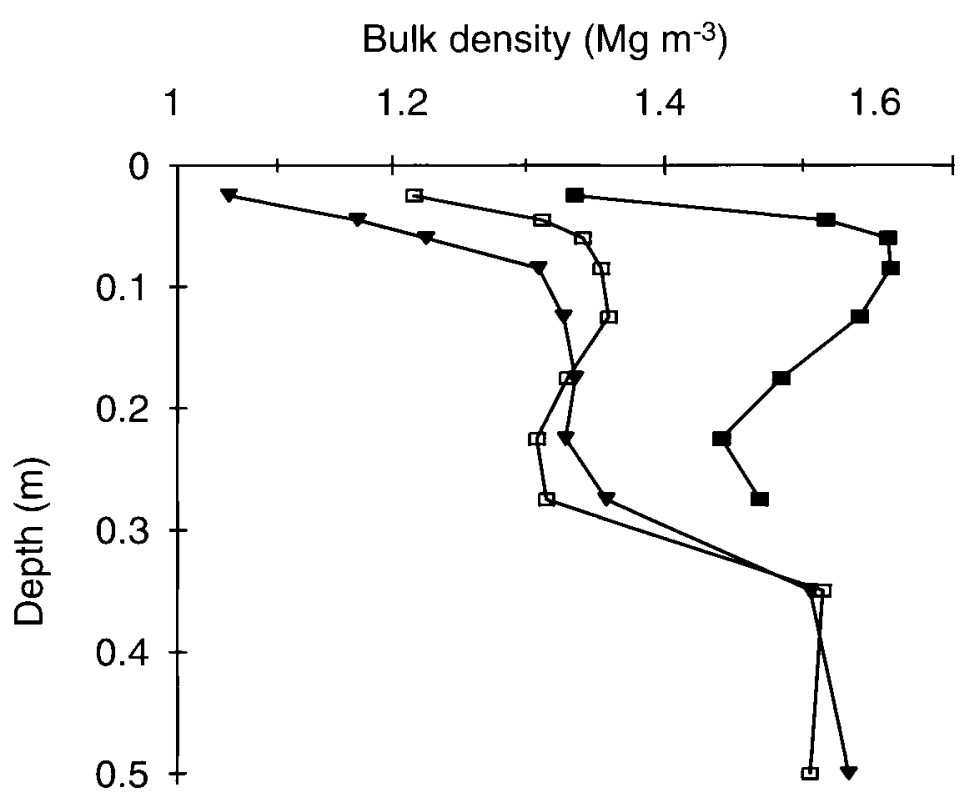

Figure 2. Dry bulk density profiles in the three plots. $\boldsymbol{\nabla}$ : Spring-tilled soil (S); $\square$ : autumn-tilled soil (A); $\mathbf{\square}$ : compacted soil (C) standard deviation: $0.08 \mathrm{Mg} \mathrm{m}^{-3}$ in plot $\mathrm{S}, 0.03 \mathrm{Mg} \mathrm{m}^{-3}$ in plots $\mathrm{A}$ and $\mathrm{C}$.

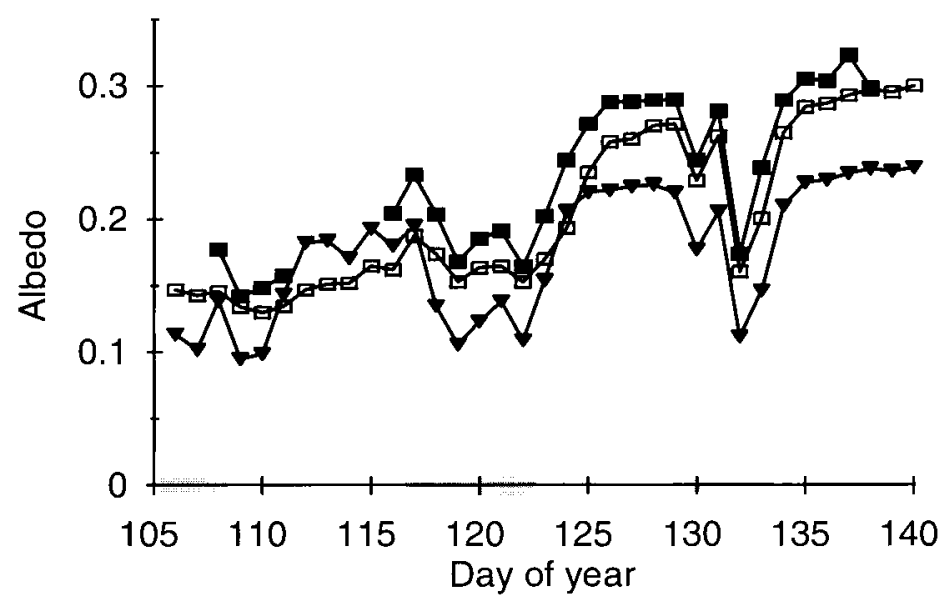

Figure 3. Changes in albedo on the three plots with time ( $\mathbf{\nabla}: \mathrm{S} ; \square: \mathrm{A} ; \mathbf{\square}: \mathrm{C}$, as in figure 2 ). $\square \quad \square$ : Rainy periods.

silt deposits on plots $\mathrm{A}$ and $\mathrm{C}$ probably produced the higher albedos.

Figure 4 shows the changes with time in the volumetric heat capacity and thermal conductivity for the three treatments. The volumetric heat capacity and thermal conductivity of the $0.00-0.02 \mathrm{~m}$ layer were lower than those at $0.05-0.10 \mathrm{~m}$ in depth. The volumetric heat capacity was higher on wet days than on dry days for all three plots, particularly in the 0.00-0.02 m layer, where the water content changed rapidly. Thermal conductivities varied more between treatments. On each plot, they 

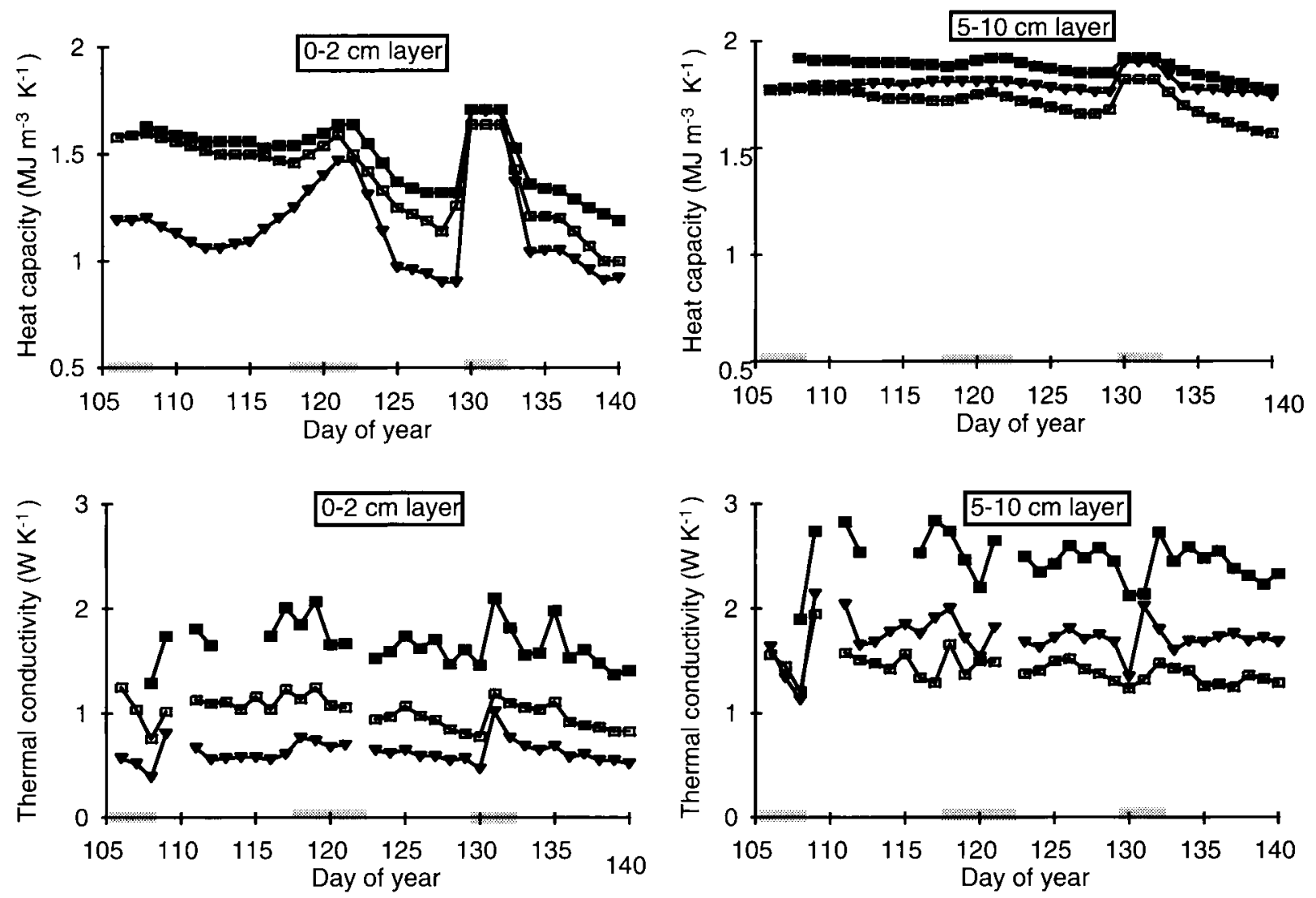

Figure 4. Changes in the volumetric heat capacity (a) and thermal conductivity (b) in the $0.00-0.02 \mathrm{~m}$ or $0.05-0.10 \mathrm{~m}$ layers with

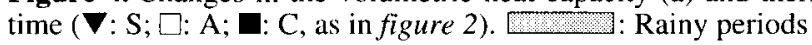

changed less with time due to climatic conditions than did the heat capacity. Volumetric heat capacity and thermal conductivity in the $0.00-0.02 \mathrm{~m}$ layer were $\mathrm{S}<\mathrm{A}<\mathrm{C}$. The maximum ratios between the heat capacities of the three plots were about 1.5 at the beginning of the experiment. The mean ratios between the thermal conductivities of plots $\mathrm{A}$ and $\mathrm{S}$ was 1.4 , that for plots $\mathrm{C}$ and $\mathrm{S}$ was 2 . The volumetric heat capacity and thermal conductivity in the $0.05-0.10 \mathrm{~m}$ layer were much more similar, except for the thermal conductivity of plot $C$, which was about twice that of plots A and S. Plot $C$ always had the highest volumetric heat capacity and thermal conductivity because of its much greater bulk density $\left(1.5 \mathrm{Mg} \mathrm{m}^{-3}\right)$.

\subsection{Water regime of the ploughed layer}

The changes in water content with time and depth for each dry period are shown in figure 5 . The first water content profile was measured on day 108 , just before rainfall (figure 1). The topsoil $(0.00-0.05 \mathrm{~m})$ of plot $\mathrm{S}$ was dry, while the topsoils of $\mathrm{A}$ and $\mathrm{C}$ were wet, corresponding to a water suction of $100 \mathrm{kPa}$. The $5 \mathrm{~mm}$ of rain during the evening of day 108 rewetted topsoil of S, probably giving it a soil moisture similar to that of topsoils $\mathrm{A}$ and $\mathrm{C}$. The topsoil of $\mathrm{S}$ was already dry on day 112 and later on day 115 , while the topsoils of $\mathrm{A}$ and $C$ remained wet. Thus, the $S$ topsoil dried 
Plot S -Dry period 1

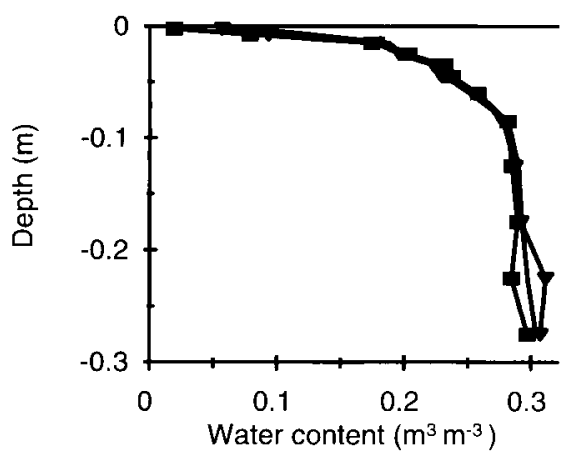

Plot S - Dry period 2

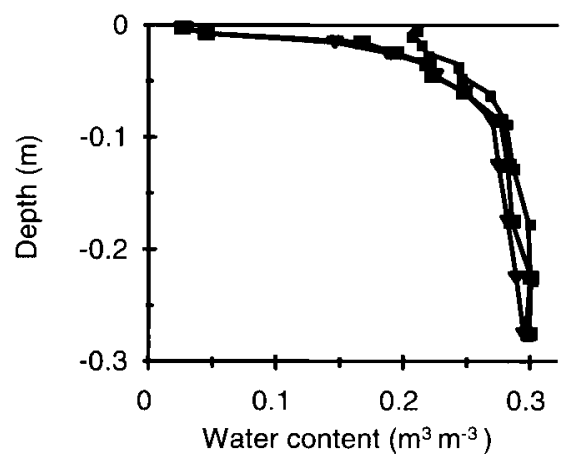

Plot S - Dry period 3

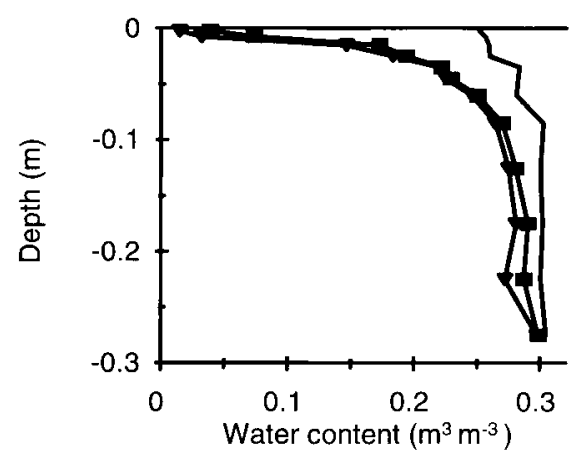

Plot A - Dry period 1

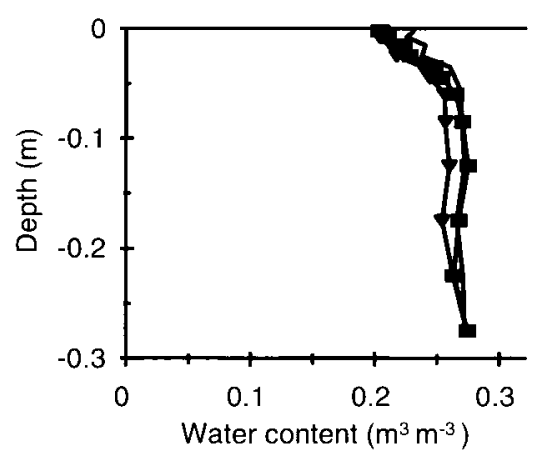

$-108+112+115$

Plot A - Dry period 2

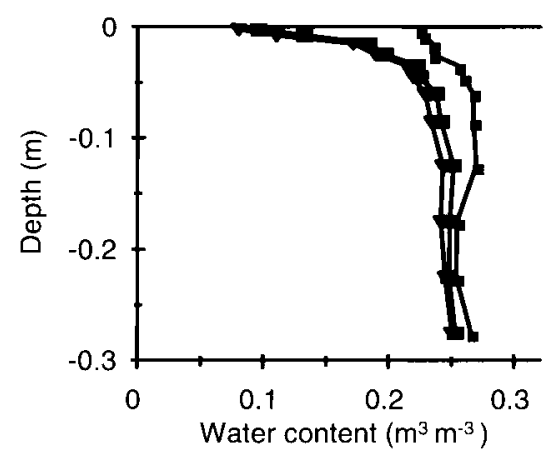

$-121+125+127$

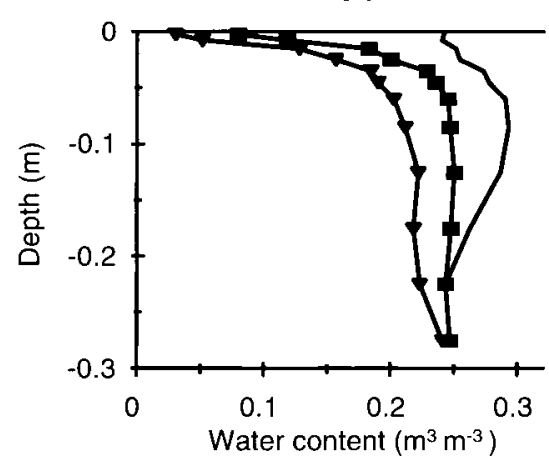

Plot C - Dry period 3

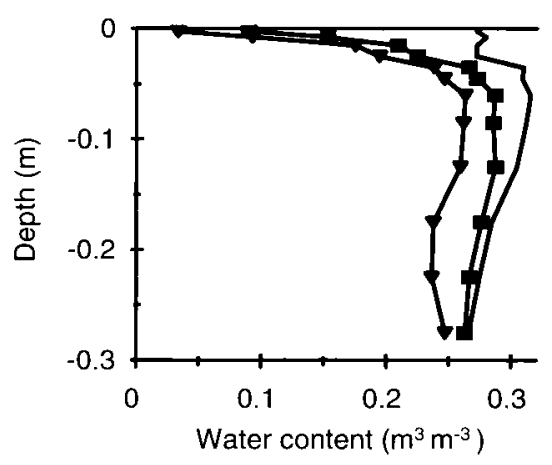

Plot C - Dry period 1

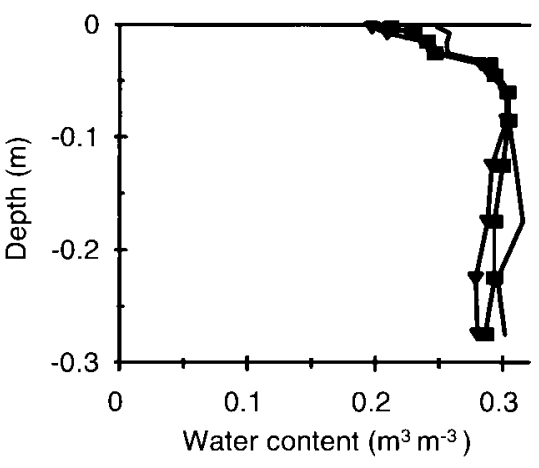

Plot C - Dry period 2

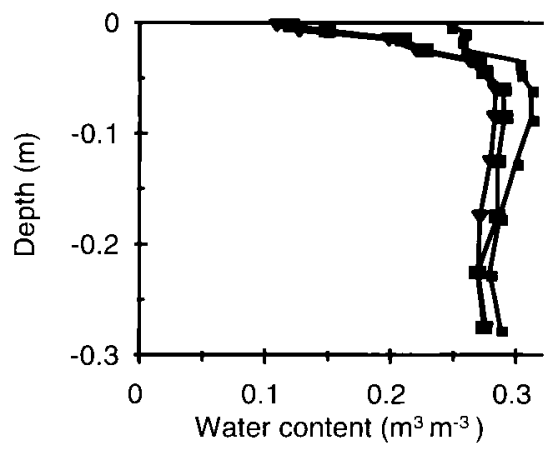

$-132 \div-134-139$

Figure 5. Changes in the soil water content during the three dry periods with time and depth. Standard deviation: $0.01 \mathrm{~m}^{3} \mathrm{~m}^{-3}$ in the $0-0.05 \mathrm{~m}$ layer, less than $0.05 \mathrm{~m}^{3} \mathrm{~m}^{-3}$ for depth $>0.05 \mathrm{~m}$. 
quicker than the $\mathrm{A}$ and $\mathrm{C}$ topsoils during the first dry period. Conversely, the topsoils of plots A and $\mathrm{C}$ also dried out during the second and third dry periods. The effects of tillage on the soil surface drying were also visible in the change in albedo. The albedo of plot A was lower than that of plot S during the first dry period (figure 3), but higher during the other two dry periods when the soil surface water contents of the three plots were similar.

Changes in water content with time between plots below a depth of $0.05 \mathrm{~m}$ were the opposite of those in the topsoil. Water content remained more constant within plot $\mathrm{S}$ than within plots $\mathrm{A}$ and $\mathrm{C}$ during the three dry periods.

\subsection{Thermal regime of the ploughed layer}

Figure $6 a$ shows the mean daily temperatures on the three treatments at $0.02 \mathrm{~m}$ in depth. Plot $\mathrm{S}$ was warmer than plot $\mathrm{A}$, which was warmer than plot C. During the dry periods, the absolute difference in the mean day temperatures between plots $\mathrm{A}$ and $\mathrm{S}$ was $0.5-1.0 \mathrm{~K}$, and it was $0.5-1.5 \mathrm{~K}$ between plots $\mathrm{C}$ and $\mathrm{S}$. The three plots had the same temperature during the rainy periods. Figure $6 b, c$ shows the differences in the maximum and minimum daily temperatures between plots $\mathrm{A}$ or $\mathrm{C}$ and plot S. Maximum soil temperatures were generally $\mathrm{S}>\mathrm{A}>\mathrm{C}$, while the minimum soil temperatures were $\mathrm{C}>\mathrm{S}>\mathrm{A}$. The range of maximum soil temperature was greater than that of minimum soil temperature. The difference in maximum soil temperatures rose to a maximum immediately after rainy periods and then decreased during the dry periods. Similarly, the differences in minimum soil temperature changed as the soil dried.

The overall effect of the treatments on the soil thermal regime is shown in table II, which indicates the overall means of the mean, maximum and minimum soil temperature, and daily amplitude for rainy and dry periods. Dry periods were warmer than rainy periods. Mean soil temperature decreased with increasing depth only during dry periods. The mean soil temperatures were $\mathrm{S}>\mathrm{A}>\mathrm{C}$ during the dry periods, and were similar during the rainy periods.
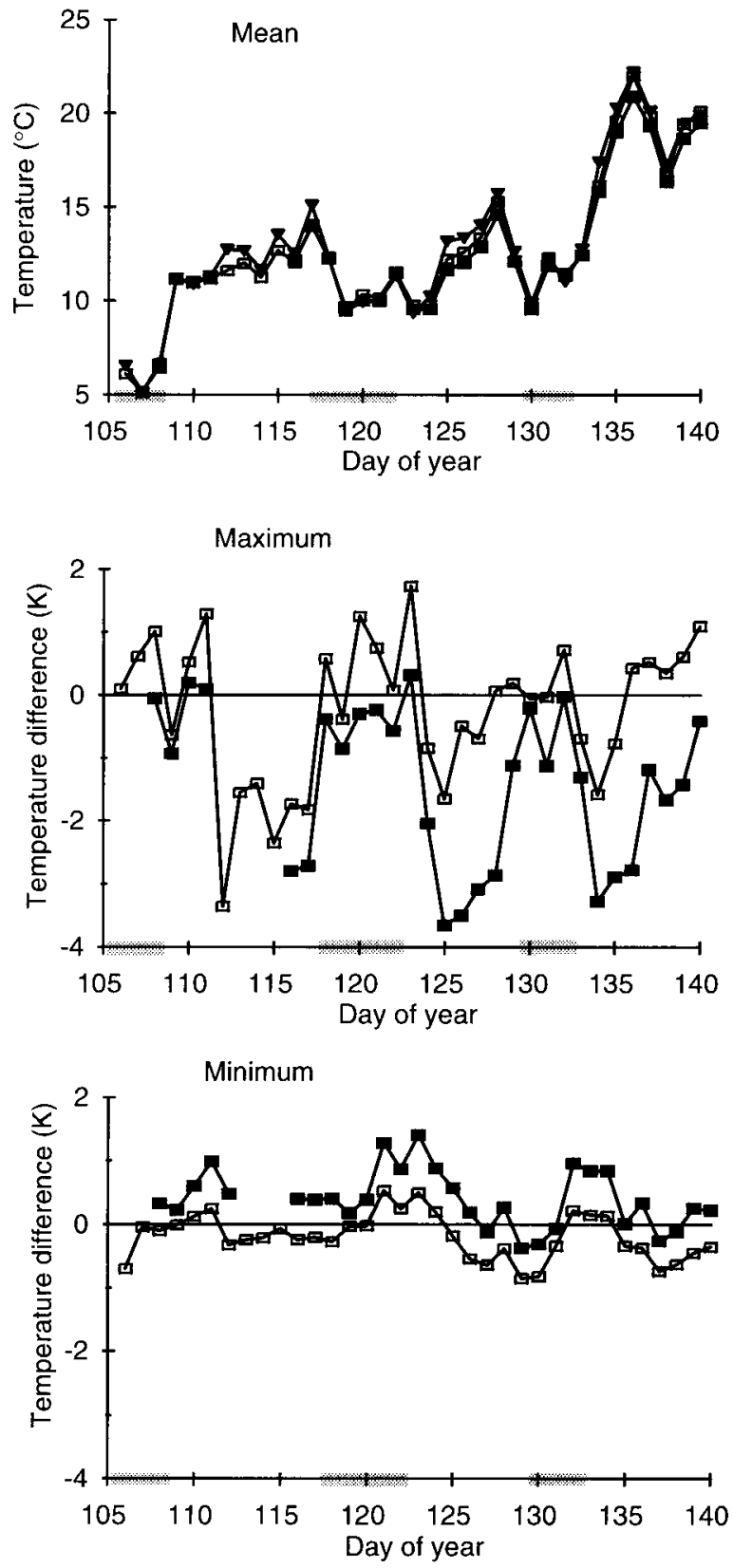

Figure 6. Changes in mean daily temperature at a depth of $0.02 \mathrm{~m}$ with time ( $\boldsymbol{\nabla}: \mathrm{S} ; \square: \mathrm{A} ; \mathbf{\mathbf { w }}: \mathrm{C}$, as in figure 2) (a), differences in the maximum (b) or minimum (c) soil temperature at a depth of $0.02 \mathrm{~m}$ between plots $\mathrm{A}$ and $\mathrm{S}(\bullet)$ and between plots $\mathrm{C}$ and $\mathrm{S}(\mathbf{D})$. Rainy periods.

The maximum temperatures were $\mathrm{S}>\mathrm{A}>\mathrm{C}$ at the soil surface, and were similar on all three plots at depths $>0.05 \mathrm{~m}$. The minimum temperatures varied less between plots than did the maximum soil tem- 
Table II. Soil temperature during the experimental period (year days 106-137) as a function of soil depth and treatment.

\begin{tabular}{|c|c|c|c|c|c|c|}
\hline \multirow[t]{2}{*}{ Depth (m) } & \multicolumn{3}{|c|}{ Rainy periods } & \multicolumn{3}{|c|}{ Dry periods } \\
\hline & $S$ & $\mathrm{~A}$ & $\mathrm{C}$ & S & A & $\mathrm{C}$ \\
\hline \multicolumn{7}{|c|}{ Mean } \\
\hline Air & 9.4 & 9.3 & & 13.2 & 13.1 & \\
\hline 0.00 & 9.9 & 9.8 & 9.8 & 15.1 & 14.6 & 14.4 \\
\hline 0.02 & 9.7 & 9.7 & 9.5 & 14.5 & 14.2 & 13.8 \\
\hline 0.05 & 9.8 & 9.6 & 9.6 & 14.2 & 13.9 & 13.8 \\
\hline 0.10 & 9.7 & 9.5 & 9.5 & 13.7 & 13.4 & 13.4 \\
\hline 0.20 & 9.8 & 9.5 & 9.5 & 12.7 & 12.4 & 12.6 \\
\hline 0.50 & 9.8 & 9.5 & 9.5 & 11.0 & 11.5 & 11.0 \\
\hline \multicolumn{7}{|c|}{ Maximum } \\
\hline Air & 13.0 & 12.8 & & 18.6 & 18.4 & \\
\hline 0.00 & 16.1 & 15.7 & 15.0 & 26.9 & 24.9 & 23.7 \\
\hline 0.02 & 13.6 & 13.8 & 13.0 & 22.0 & 21.9 & 20.2 \\
\hline 0.05 & 12.8 & 13.1 & 12.6 & 20.1 & 20.5 & 19.1 \\
\hline 0.10 & 11.5 & 11.8 & 11.7 & 17.5 & 17.6 & 17.5 \\
\hline 0.20 & 10.7 & 10.5 & 10.7 & 14.5 & 14.3 & 14.7 \\
\hline 0.50 & 10.1 & 10.0 & 9.8 & 11.4 & 12.3 & 11.5 \\
\hline \multicolumn{7}{|c|}{ Minimum } \\
\hline Air & 5.1 & 4.9 & & 7.0 & 7.0 & \\
\hline 0.00 & 4.0 & 4.4 & 4.8 & 5.8 & 6.4 & 6.9 \\
\hline 0.02 & 5.6 & 5.4 & 5.9 & 7.8 & 7.6 & 8.2 \\
\hline 0.05 & 6.5 & 5.8 & 6.4 & 8.7 & 8.1 & 8.8 \\
\hline 0.10 & 7.6 & 7.0 & 7.0 & 10.0 & 9.4 & 9.5 \\
\hline 0.20 & 8.8 & 8.4 & 8.2 & 11.1 & 10.7 & 10.6 \\
\hline 0.50 & 9.5 & 9.2 & 9.3 & 10.7 & 10.9 & 10.6 \\
\hline \multicolumn{7}{|c|}{ Amplitude } \\
\hline Air & 7.9 & 7.9 & & 11.6 & 11.4 & \\
\hline 0.00 & 12.1 & 11.3 & 10.2 & 21.0 & 18.5 & 16.8 \\
\hline 0.02 & 8.0 & 8.3 & 10.2 & 14.2 & 14.3 & 12.1 \\
\hline 0.05 & 6.3 & 7.3 & 6.2 & 11.4 & 12.4 & 10.3 \\
\hline 0.10 & 3.8 & 4.8 & 4.7 & 7.5 & 8.2 & 8.0 \\
\hline 0.20 & 1.9 & 2.2 & 2.5 & 3.4 & 3.6 & 4.2 \\
\hline 0.50 & 0.6 & 0.8 & 0.4 & 0.7 & 1.4 & 0.8 \\
\hline
\end{tabular}

The deepest temperature probe on plot A was at $0.35 \mathrm{~m}$ instead of $0.50 \mathrm{~m}$.

Rainy period $=$ days $105 / 108+117 / 122+130 / 132$.

Dry periods $=$ days $109 / 116+123 / 129+133 / 137$.

peratures. The minimum daily soil temperature was higher on plot $\mathrm{C}$ at depths $<0.05 \mathrm{~m}$, while it was higher on plot $\mathrm{S}$ for depths $>0.05 \mathrm{~m}$. Plot $\mathrm{A}$ was the coolest, except at $0 \mathrm{~m}$. The decrease in amplitude with increasing depth in the first $5 \mathrm{~cm}$ was most marked in plot $S$, but at depths $>0.05 \mathrm{~m}$ it was rather similar in all three plots.

\subsection{Energy balance at the soil surface}

The soil heat fluxes, averaged over $24 \mathrm{~h}$, were similar for plots $\mathrm{A}$ and $\mathrm{S}$, but higher for plot $\mathrm{C}$ (figure $7 a$ ). The fluxes averaged over the day-time and night-time periods were different on the three 


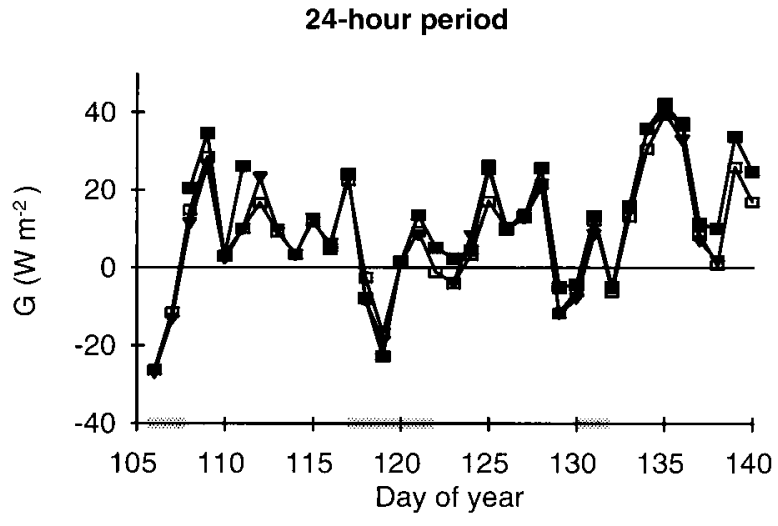

Day period (7 a.m. - 5 p.m.)

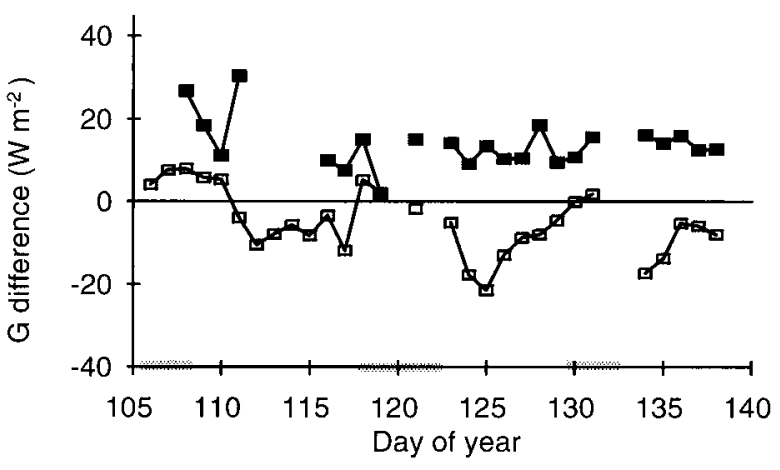

Night period (8 p.m. - 5 a.m.)

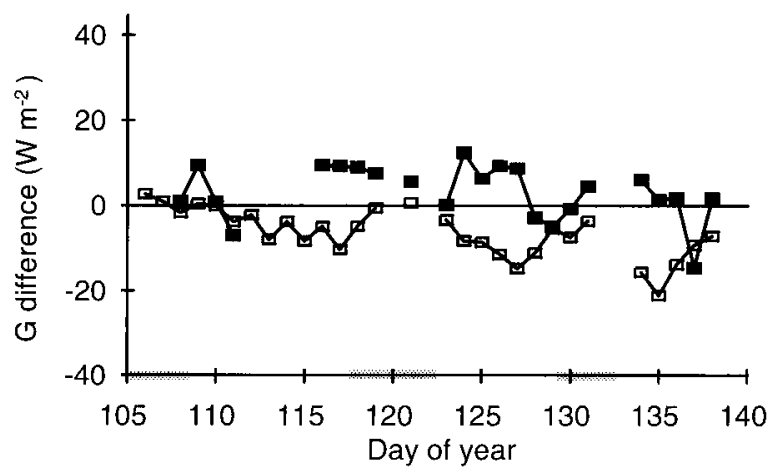

Figure 7. Changes in (a) mean soil heat flux at the soil surface (24-h period) ( $\nabla: \mathrm{A} ; \square: \mathrm{S} ; \mathbf{\square}: \mathrm{C}$, as in figure 2 ), (b) differences in day-time ( 7 a.m. -5 p.m.) and (c) absolute night-time (7 p.m.-5 a.m.) soil heat fluxes between plots $A$ and $S(\square)$ and between plots $\mathrm{C}$ and $\mathrm{S}(\mathbf{\square})$. Rainy periods.

plots, as shown in figure $7 b, c$, which displays the differences in the day ( 7 a.m. -5 p.m.) or night (8 p.m. -5 a.m.) soil heat fluxes between plots $A$ and $S$, and between plots $C$ and $S$ (absolute values of fluxes for the night period). The soil heat flux was greatest in plot $\mathrm{C}$ during both the day and the night, which indicates that more heat was stored during the day and more heat was lost during the night. In contrast, plot $\mathrm{A}$ had the lowest soil heat fluxes (in absolute value). The difference in the soil heat fluxes for plots $A$ and $S$ decreased as the soil dried during the second and the third dry periods.

Figure 8 shows the changes with time in net radiation $(8 a)$, sensible heat flux $(8 b)$ and latent heat flux $(8 c)$ for plots $\mathrm{A}$ and $\mathrm{S}$, averaged over the day period ( 7 a.m. -5 p.m.). The latent heat flux was the main flux during the rainy periods, when sensible heat fluxes were nearly zero. It progressively decreased during the dry periods as the soil surface dried. In contrast, soil heat flux and atmospheric sensible heat flux increased. Net radiation was higher on plot $\mathrm{S}$ than on plot $\mathrm{A}$ ( $8 \%$ difference from the mean for the whole experimental period). It was similar on the two plots at the end of the first dry period, at which time the albedo of plot A was lower than that of plot $S$ (figure 3 ) because of the higher water content of the soil surface (figure 5). The sensible heat flux in the atmosphere was higher on plot $S$ than on plot A $(40 \%$ difference from the mean for the whole experimental period), particularly during the first dry period. The latent heat flux was smaller on plot $S$ than on plot A, except during the third dry period when it was similar on the two plots. The difference was about $20 \%$ (relative to the mean) during the first dry period (corresponding to differences in evaporation of $\left.0.5 \mathrm{~mm} \mathrm{day}^{-1}\right)$.

\section{DISCUSSION}

We will examine how tillage modified the soil properties that influenced the soil thermal regime, the energy balance, the soil temperature and finally the effect of tillage on sugar beet emergence.

\subsection{Soil properties}

The difference in albedo of 0.05 between a smooth soil surface due to crust formation and a 

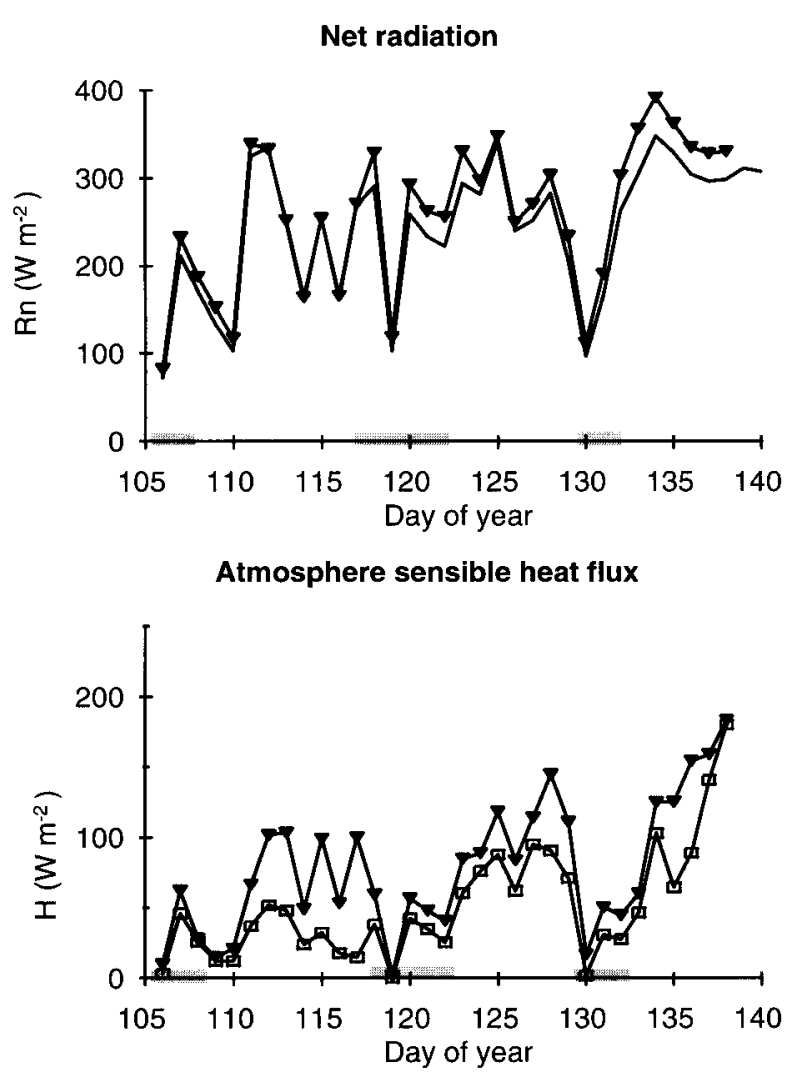

Latent heat flux

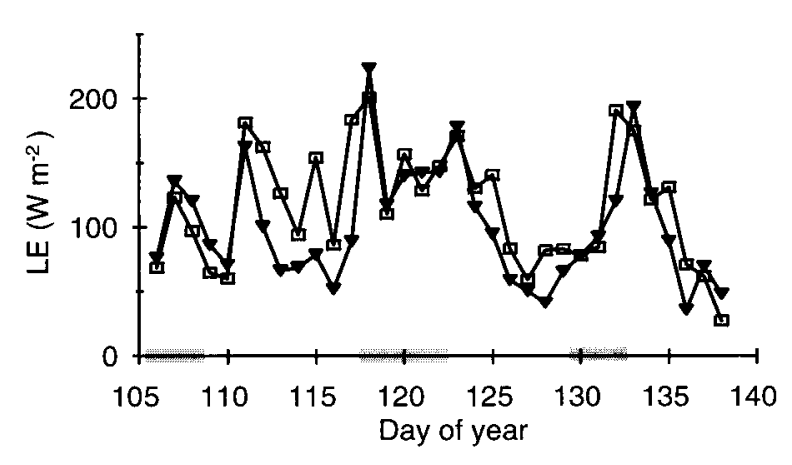

Figure 8. Changes in net radiation, atmospheric sensible heat flux and latent heat flux on the spring-tilled plot $(\nabla)$ and the autumn-tilled plot $(\square)$. $\square$ : Rainy periods.

freshly tilled soil was similar to those reported by Cipra et al. [10] and Idso et al. [21]. Soil compaction greatly increased thermal conductivity (about $200 \%$ at $0.05 \mathrm{~m}$ deep), and gave a smaller increase in heat capacity (about $20 \%$ at $0.05 \mathrm{~m}$ deep), as observed by Allmaras et al. [3]. This con- firms the great effect of soil bulk density on changes in thermal conductivity, as measured by Bussière et al. [6] using thermal probes. The timing of the secondary tillage had a smaller effect on thermal conductivity than did soil compaction. The increase in thermal conductivity and heat capacity with the autumn soil tillage by $10-20 \%$ was similar to the changes observed by Johnson and Lowery [23] and Arshad and Azooz [1], who compared the spring thermal regimes of conventional tilled soils (equivalent to the spring-tilled soil $S$ in our experiment) and untilled soils (without crop residues, equivalent to the autumn-tilled soil $\mathrm{A}$ in our experiment).

We shall deal with net radiation, evaporation and sensible heat fluxes to analyse the energy balance. Net radiation defines the energy available at the soil surface; evaporation is strongly linked to water availability and so to previous climatic conditions (the days before), while the sensible heat fluxes in the soil and in the atmosphere reflect mainly instantaneous meteorological conditions and are strongly linked to the surface temperature (equations (3) and (4)).

\subsection{Net radiation}

Net radiation depends on the solar and atmospheric radiation, the soil surface temperature, and the soil albedo and emissivity (equation (2)). Table III shows the radiation balance and some of its components from instantaneous data (averaged over $1 \mathrm{~h}$ for a day with high solar radiation, when the differences in radiation balance and surface temperature between plots are likely to be greatest), and from data averaged over the whole experimental period. The difference in net radiation from instantaneous data was mainly due to a difference in reflected radiation, but the difference in the soil surface temperatures of the two soil tillage timings compensated for more than half the difference due to albedo. Similar results were obtained by Allmaras et al. [3] for the net radiation on ploughed (high albedo and cold soil) and ploughed + harrowed (low albedo and warm soil) plots. But 
Table III. Analysis of the radiation balance.

\begin{tabular}{lcccccc}
\hline & $\begin{array}{c}R_{s} \\
\left(\mathrm{~W} \mathrm{~m}^{-2}\right)\end{array}$ & $a$ & $\begin{array}{c}(1-a) R_{s} \\
\left(\mathrm{~W} \mathrm{~m}^{-2}\right)\end{array}$ & $\begin{array}{c}T_{0} \\
\left({ }^{\circ} \mathrm{C}\right)\end{array}$ & $\begin{array}{c}-\sigma T_{0}^{4} \\
\left(\mathrm{~W} \mathrm{~m}^{-2}\right)\end{array}$ & $\begin{array}{c}R_{n} \\
\left(\mathrm{~W} \mathrm{~m}^{-2}\right)\end{array}$ \\
\hline $\begin{array}{l}\text { Day 128 at 12 noon } \\
\text { Autumn tillage (A) }\end{array}$ & 798 & 0.27 & 580 & 27.8 & -464 & 425 \\
$\begin{array}{l}\text { Spring tillage (S) } \\
\text { Difference A-S }\end{array}$ & 798 & 0.23 & 616 & 31.2 & -486 & 447 \\
Experimental period & & & -36 & & 22 & -22 \\
Autumn tillage (A) & 191 & 0.21 & 151 & 12.3 & -378 & 89 \\
Spring tillage (S) & 191 & 0.17 & 159 & 12.8 & -380 & 97 \\
Difference A-S & & & -8 & & 2 & -8 \\
\hline
\end{tabular}

$R_{s}:$ solar radiation; $R_{n}$ : net radiation; $a$ : albedo; $T_{0}:$ soil surface temperature.

$\sigma:$ Stefan-Boltzmann constant.

the temperature differences $(6 \mathrm{~K}$ for a 12 -h average) were undoubtedly due to the great difference in soil roughness in this case. The difference in soil surface temperature was smaller when the whole period was considered, because it combined data with low and high solar radiation and with dry and wet soil. The difference in reflected radiation averaged over the whole period remained much larger than the differences in emitted long-wave radiation: consequently the spring-tilled soil had a higher net radiation input than the autumn-tilled soil. The compacted soil and the autumn-tilled soil probably had similar net radiations because of the small differences in their albedo and surface temperatures.

\subsection{Latent heat flux}

Evaporation depends on the vapour saturation deficit above the soil surface, the aerodynamic resistance to water vapour transfer $\left(r_{a}\right)$ and the soil resistance to water transfer $\left(r_{s}\right)$ (equation (6)). Evaporation decreased steadily each day after rainfall because the soil surface dried and soil resistance to evaporation increased (figure $9 a, b$ ), as reported by Idso et al. [19]. The aerodynamic resistance to water vapour transfer had little effect on evaporation: $r_{a}$ was much smaller than $r_{s}$, and it increased less than did $r_{s}$ (figure $9 a, b$ ). The decrease in evaporation varied greatly according to soil tillage and the dry period (figure $8 c$ ). Soil surface resistance to evaporation increased much more rapidly after rain on the spring-tilled soil, especially during the two first dry periods (days 108-117 and 123-129) when the soil surface dried more quickly. Surface water content decreased more rapidly on the spring-tilled soil because water transfer to the soil surface was probably less efficient in the spring-tilled soil than in the autumntilled soil. The structural discontinuity between the seed bed and the sub-layer caused by the spring tillage and the greater porosity of the first few centimetres of the soil should have decreased the hydraulic conductivity within the spring-tilled soil. Such an increase in evaporation with increasing bulk density and compaction was mentioned by Hadas [16], although the effect of soil structure on hydraulic conductivity is not well known [18]. The soil surface of the autumn-tilled soil also dried out and the soil surface resistance to evaporation increased during the third dry period when potential evaporation was high $\left(5 \mathrm{~mm} \mathrm{day}^{-1}\right)$. In this case, there was no difference in soil evaporation between the two tillage timings. The autumn-tilled soil counteracted evaporation by supplying the soil surface with water by capillarity, because of its rel- 
(a) Air resistance

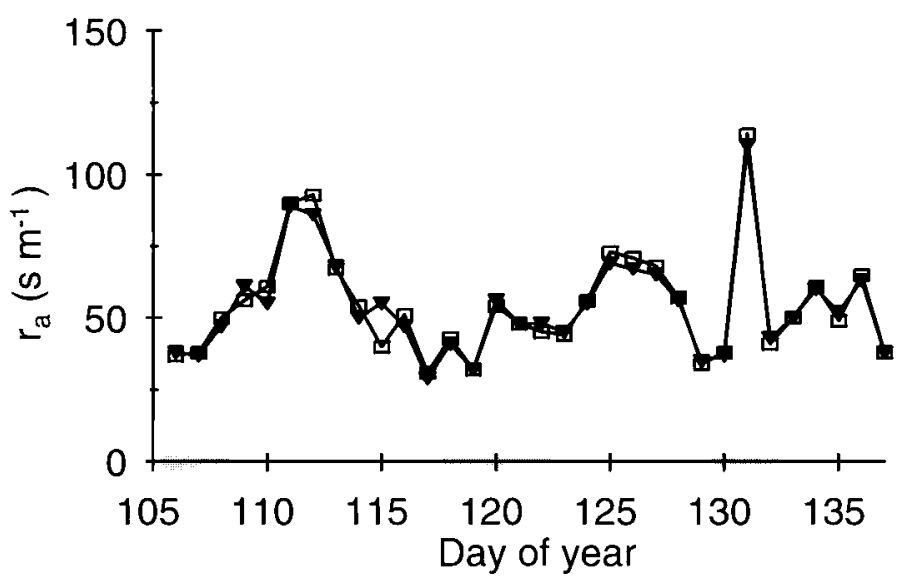

(b) Soil resistance

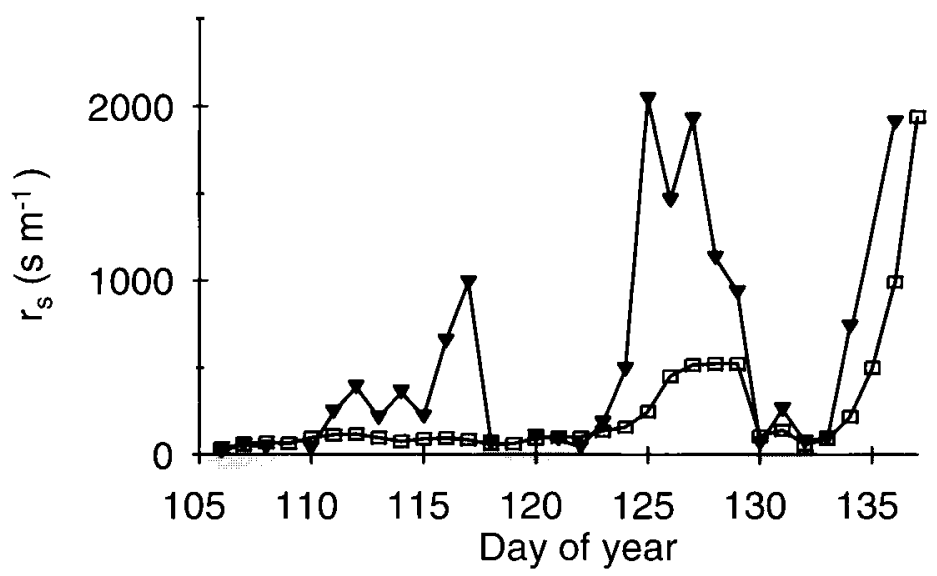

Figure 9. Aerodynamic resistance to heat and water vapour transfer $\left(r_{u}\right)$ and soil resistance to water transfer $\left(r_{s}\right)$ for the spring-tilled plot $(\boldsymbol{\nabla})$ and the autumn-tilled plot $(\square)$. $\square$ : Rainy periods

atively high hydraulic conductivity, only when the low climatic demand was low. The effect of soil tillage on evaporation appears to be closely correlated with climatic conditions.

\subsection{Soil heat flux}

Net radiation was higher on the spring-tilled soil than on the autumn-tilled soil, and it was the reverse for the latent heat flux. Thus, there was more energy available for the sensible heat fluxes $\left(H+G=R_{n}-\lambda E\right)$ on the spring-tilled soil than on the autumn-tilled soil (table $I V$ ). This produced a greater sensible heat flux and a greater soil heat flux on the spring-tilled soil than on the autumntilled soil. But the fraction of the available energy that went into the soil $\left(G /\left(R_{n}-\lambda E\right)\right)$ was smaller on the spring-tilled soil than on the autumn-tilled soil (table IV), and it was obviously the opposite 
for the ratio $H /\left(R_{n}-\lambda E\right)$. On the contrary, the differences in net radiation and latent heat flux for the compacted and the autumn-tilled soils were probably very small (the similar changes in water content with time and depth for the two treatments (figure 5) indicate similar evaporation). In these conditions, soil heat flux and $\left(G /\left(R_{n}-\lambda E\right)\right)$ were higher on the compacted soil than on the autumntilled soil. The atmospheric sensible heat flux depends on the thermal gradient above the soil surface and aerodynamic resistance to heat transfer (equation (5)), while the soil heat flux depends on the thermal gradient at the soil surface and the soil surface thermal conductivity (equation (4)). The air resistance for the two tillage timings was similar (figure 9a), while the thermal conductivity was lower on the spring-tilled soil than on the autumntilled soil and it was highest on the compacted soil (figure 4). The thermal conductivity probably limited the penetration of heat into the soil on the spring-tilled soil, despite the greater available energy; but it enhanced heat penetration into the compacted soil. It was already observed that the soil heat flux and $G / R_{n}$ ratios over the same soil with different water contents were first related to differences in evaporation and then to differences in soil thermal properties $[12,20]$.

\subsection{Soil temperature}

The change in soil temperature with time is proportional to the soil heat flux $G$ and inversely proportional to the soil heat capacity $C$ (equation (3)). The differences in soil temperature between the three treatments were more pronounced during the day than during the night, because the soil heat flux is higher during the day than during the night in the spring; they were about $0-2 \mathrm{~K}$ in the whole ploughed layer, in the same range as in previous studies. The soil temperatures of the three plots were in the reverse order from their volumetric heat capacities, they were not in the order of soil heat fluxes: the differences in soil heat flux on the three plots were counteracted by the differences in heat capacity. This was not so in the experiment of Allmaras et al. [3], where soil temperatures were in the same sequence as soil heat flux. The differences in soil heat flux were due to the difference in random roughness and flux towards the atmosphere, they were much larger $(40 \%)$ than those in our experiment $(10 \%)$. The differences in soil temperature were transient and linked to the climatic conditions; they occurred only during the transition conditions following a rainfall event. Soil heat fluxes were low during rainy periods, due to high

Table IV. Mean net radiation $\left(R_{n}\right)$, soil heat flux $(G)$, atmospheric sensible heat flux $(H)$ and latent heat flux $(\lambda E)$ during the day (7 a.m. -5 p.m.) $\left(\mathrm{W} \mathrm{m}^{-2}\right)$, and percentage of net radiation to the soil heat flux, atmospheric sensible heat flux and latent heat flux (in parenthesis) for autumn soil tillage and spring soil tillage, for rainy and dry periods.

\begin{tabular}{lcccc}
\hline \multicolumn{2}{c}{ Rainy periods } & \multicolumn{2}{c}{ Dry periods } \\
\hline$R_{n}$ & Autumn tillage & Spring tillage & Autumn tillage & Spring tillage \\
$G$ & 196 & 220 & 260 & 279 \\
$H$ & $42(20 \%)$ & $53(21 \%)$ & $87(33 \%)$ & $95(33 \%)$ \\
$\lambda E$ & $24(10 \%)$ & $43(18 \%)$ & $61(23 \%)$ & $94(34 \%)$ \\
$R_{n}-\lambda E$ & $131(70 \%)$ & $123(61 \%)$ & $112(44 \%)$ & $90(33 \%)$ \\
$G /\left(R_{n}-\lambda E\right)$ & 65 & 97 & 148 & 189 \\
\hline
\end{tabular}


evaporation, and similar on the three plots, soil heat capacities were high, due to high water content, and similar. The spring-tilled soil became warmer immediately after rainfall, because it had a high soil heat flux - due to low evaporation, and in spite of its low thermal conductivity - and a low heat capacity - due to its low water content. Differences in soil temperature logically decreased as the soil was drying: soil heat flux became less different between the three treatments, because evaporation and thermal conductivity became low even in the autumn-tilled and compacted soils, and heat capacity also became less different between the three treatments.

\subsection{Crop establishment}

The effect of the soil tillage timing on crop establishment was significant, even though the differences in soil temperature were small. The time necessary to reach $50 \%$ of germinated seeds was shorter for the spring-tilled soil ( 8 days) than for the autumn-tilled soils ( 10 days). The time necessary to reach $50 \%$ of emerged seedlings was less pronounced between the two tillage timings, 14 days for the spring-tilled soil and 15 days for the autumntilled soil, because the sowing depth was also modified by soil tillage. The sowing was more superficial for the autumn-tilled soil $(0.010 \mathrm{~m} \pm 0.006 \mathrm{~m})$ than for the spring-tilled soil $(0.017 \mathrm{~m} \pm 0.006 \mathrm{~m})$; the seeder had difficulty penetrating the autumn-tilled plot because of the degraded soil surface.

\section{CONCLUSION}

This study demonstrates that the effects of tillage on the soil thermal regime are significant, but complex and contradictory, and that it is essential to describe the energy balance of the soil surface to understand its effects. Tilling the soil just before sowing increased the energy available to warm the soil by reducing evaporation, increased soil temperature and enhanced sugar beet emergence. But tilling the soil also modified albedo and thermal properties. The overall effect of tillage depends on its effect on each soil parameter, and there is also a strong interaction with climatic conditions. For example, tilling the soil before sowing did not alter the soil temperature when the soil was dry. The positive effect of spring tillage on soil temperature can also be counteracted if the soil is compacted during tillage. Consequently, we need a soil temperature simulation model to define precisely the soil structure required to enhance soil warming under various climatic conditions, and thus to define the best tillage strategy. The physical-based model for predicting soil temperature should take into account heat transfer into the soil, and as this study shows, the transfer of water into the soil, so as to predict soil evaporation within the energy balance at the soil surface. We will use our data to calibrate the model of Chanzy and Bruckler [9], which describes these physical processes, and then analyse the sensivity of this model.

Acknowledgements: The authors thank D. Boitez and C. Dominiarczyk for technical assistance, and O. Parkes for checking the English text.

\section{REFERENCES}

[1] Arshad M.A., Azooz R.H., Tillage effects on soil thermal properties in a semiarid region, Soil Sci. Soc. Am. J. 60 (1996) 561-567.

[2] Allmaras R.R., Nelson W.W., Hallauer E.A., Fall versus spring plowing and related heat balance in the western Corn Belt, Minn. Agric. Stn Tech. Bull. 283 (1972) 1-22.

[3] Allmaras R.R., Hallauer E.H., Nelson W.W., Evans S.D., Surface energy balance and soil thermal property modifications by tillage-induced soil structure, Minn. Agric. Stn Tech. Bull. 306 (1977) 1-40.

[4] Boiffin J., Durr C., Fleury A., Marin Laflèche A., Maillet I., Analysis of the variability of sugar beet (Beta vulgaris) growth during the early stages. I Influence of various conditions on crop establishment, Agronomie 12 (1992) 515-525.

[5] Brutsaert W.H., Evaporation into the Atmosphere, Reidel, Dordrecht, 1982. 
[6] Bussière F., Cellier P., Dorigny A., Estimation de la conductivité thermique d'un sol in situ à l'aide d'une sonde à choc thermique, Agronomie 12 (1992) 69-78.

[7] Camillo P., Gurney R.J., A resistance parameter for bare-soil evaporation models, Soil Sci. 141 (1986) 95-105.

[8] Cellier P., Richard G., Robin P., Partition of sensible heat fluxes into bare soil and the atmosphere, Agric. For. Meteorol. 82 (1996) 245-265.

[9] Chanzy A., Bruckler L., Significance of soil moisture with respect to daily soil evaporation, Water Resour. Res. 29 (1993) 1113-1125.

[10] Cipra J.E., Baumgardner M.F., Stoner E.R., MacDonald R.B., Measuring radiance characteristics of soil with a field spectroradiometer, Soil Sci. Soc. Am. J. 35 (1971) 1014-1017.

[11] de Vries D.A., Thermal properties of soils, in: Van Wijk W.R. (Ed.), Physics of Plant Environment, North-Holland Publishing Company, Amsterdam, 1963, pp. 210-235.

[12] Fuchs M., Hadas A., The heat flux density in a non-homogeneous bare loessial soil, Bound. Layer Meteorol. 3 (1972) 191-200.

[13] Gauer E., Shaykewith C.F., Stobbe E.H., Soil temperature and soil water content under zero tillage in Manitoba, Can. J. Soil Sci. 62 (1982) 311-325.

[14] Griffith D.R., Mannering J.V., Galloway H.M., Parsons S.D., Richey C.B., Effect of eight tillage-planting systems on soil temperature, percent stand, plant growth, and yield corn on five Indiana soils, Agronomy J. 65 (1973) 321-326.

[15] Gupta S.C., Radke J.K., Larson W.E., Predicting temperatures of bare and residue covered soils with and without a crop, Soil Sci. Soc. Am. J. 45 (1981) $405-412$.

[16] Hadas A., Soil tilth: the desired soil structural state obtained through proper soil fragmentation and reorientation processes, Soil Tillage Res. 43 (1997) 7-40.

[17] Ham J.M., Senock R.S., On the measurement of soil surface temperature, Soil Sci. Soc. Am. J. 56 (1992) 370-377.

[18] Horton R., Ankeny M.D., Allmaras R.R., Effects of compaction on soil hydraulic properties, in: Soane B.D., van Ouwerker C. (Eds.), Soil Compaction in Crop
Production, Developments in Agricultural Engineering no. 11, Elsevier, Amsterdam, 1994, pp. 141-166.

[19] Idso S.B., Reginato R.J., Jackson R.D., Kimball B.A., Nakayama F.S., The three stages of drying of a field soil, Soil Sci. Soc. Am. Proc. 38 (1974) 831-838.

[20] Idso S.B., Aase J.K., Jackson R.D., Net radiation-soil heat flux relations as influenced by soil water content variations, Bound. Layer Meteorol. 9 (1975) $113-122$.

[21] Idso S.B., Jackson R.D., Reginato R.J., Kimball B.A., Nakayama F.S., The dependence of bare soil albedo on soil water content, J. Appl. Meteorol. 14 (1975) 109-113.

[22] Itier B., Cellier P., Riou C., Actual evapotranspiration measurement by a simplified aerodynamic method, ASAE Advances in Evapotranspiration Symp., 1985, pp. 201-207.

[23] Johnson M.D., Lowery B., Effect of three conservation tillage practices on soil temperature and thermal properties, Soil Sci. Soc. Am. J. 49 (1985) $1547-1552$.

[24] Oliver S.A., Oliver H.R., Wallace J.S., Roberts A.M., Soil heat flux and temperature variation with vegetation, soil type and climate, Agric. For. Meteorol. 39 (1987) 257-269.

[25] Potter K.N., Horton R., Cruse R.M., Soil surface roughness effects on radiation reflectance and soil heat flux, Soil Sci. Soc. Am. J. 51 (1987) 855-860.

[26] Richard G., Cellier P., Chanzy A., Régime thermique des lits de semence, in: J. Boiffin, E. Choppin de Janvry, (Eds.), L'implantation de la betterave sucrière: un point sur les recherches actuelles, Les Colloques de l'Inra 67, Versailles, 1994, pp. 87-101.

[27] Richard G., Boiffin J., Duval Y., Direct drilling of sugar beet (Beta vulgaris L.) into a cover crop: effects on sol physical conditions and crop establishment, Soil Till. Res. 34 (1995) 169-185.

[28] Wall D.A., Stobbe E.H., The effect of tillage on soil temperature and corn (Zea mays L.) growth in Manitoba, Can. J. Plant Sci. 64 (1984) 59-67.

[29] Wierenga P.J., Nielsen D.R., Horton R., Kies B., Tillage effects on soil temperature and thermal conductivity, in: Unger P.W., Van Doren D.M. (Eds.), Predicting Tillage Effects on Soil Physical Properties and Processes, ASA Spec. Pub. 44, Madison, 1982, pp. 69-90. 